Article

\title{
Sustainable Development for Solar Heating Systems in Taiwan
}

\section{Keh-Chin Chang ${ }^{1, \dagger}$, Wei-Min Lin ${ }^{2, \dagger}$ and Kung-Ming Chung ${ }^{1, \dagger, *}$}

1 Energy Research Center, National Cheng Kung University, No. 1 University Road, Tainan 701, Taiwan; E-Mail: kcchang@mail.ncku.edu.tw

2 Department of Accounting Information, Tainan University of Technology, No. 529, Zhongzheng Road, Yongkang District, Tainan 710, Taiwan; E-Mail: t20043@mail.tut.edu.tw

$\uparrow$ These authors contributed equally to this work.

* Author to whom correspondence should be addressed; E-Mail: kmchung@mail.ncku.edu.tw; Tel.: +886-6-239-2811 (ext. 210); Fax: +886-6-239-1915.

Academic Editor: Rachel J. C. Chen

Received: 8 January 2015 / Accepted: 6 February 2015 / Published: 12 February 2015

\begin{abstract}
In response to the impact of the United Nations Framework Convention on Climate Change, developing and using renewable energy sources and technologies have become vital for managing energy supply and demand in Taiwan. The long-term subsidy programs (1986-1991, 2000-present) for solar water heaters (SWHs) launched by the Taiwanese government constitute the main driving force for market expansion. By the end of 2013, the cumulative area of installed solar collectors was 2.27 million $\mathrm{m}^{2}$. Approximately 0.3 million systems (or 1.545 million $\mathrm{m}^{2}$ ) are in operation. This corresponds to an annual collector yield of $0.92 \mathrm{TWh}$, which is equivalent to savings of 98.7 thousand tons of oil and 319 thousand tons of $\mathrm{CO}_{2}$,eq. The market-driven mechanism is associated with cost-to-benefit ratios, construction businesses, types of building architecture, degree of urbanization and household composition. The strong wind load of typhoons is another major concern. For sustaining the solar thermal industry in Taiwan, the dominant factor for disseminating SWHs in metropolitan areas involves developing building-integrated solar thermal systems. Alternative financial incentives are required for industrial heating processes in the commercial sector.
\end{abstract}

Keywords: renewable energy; solar heating system; subsidy; economic feasibility 


\section{Introduction}

Global warming and climate change caused by carbon (greenhouse gas) emissions into the atmosphere are raising worldwide concern. Some previous studies have discussed an approach for transforming the energy system to renewable energies [1-4]. Mauthner and Wiss [5] reported in 2013 that the annual energy generated by wind power, solar thermal heat, and photovoltaic sources were 662 , 281 and $160 \mathrm{TWh}$, respectively. In addition, the net energy saving, using renewable energy sources is also of practical importance for a country's socio-economic development. Thus, renewable energy has received increasing support because of its benefits to the environment. Taiwan is a densely populated island with limited natural resources, and it relies mainly on imported fuel for satisfying its energy demands. A substantial increase in energy consumption has caused primary concern for its economic development. As shown in Table 1, the total energy supply increased from $58,329 \times 10^{3} \mathrm{~kL}$ of oil equivalent (kLOE) in 1991 to $106,383 \times 10^{3}$ and 138,236 $\times 10^{3} \mathrm{kLOE}$ in 2001 and 2011, respectively. The average annual growth rate was approximately $4.4 \%$ during the past two decades [6]. For indigenous energy, as shown in Table 2, biomass and waste corresponded to the major energy resources, and hydropower accounted for $13.35 \%-23.38 \%$ of these resources. In 2011 , solar thermal and wind power constituted $3.95 \%$ and $5.21 \%$, respectively [6]. The ratio of indigenous energy to total energy supply in Taiwan, which was $2.07 \%$ in 2011 , has been gradually declining. Taiwan must inevitably face energy crisis in the near future. Thus, National Energy Conferences were convened in 1998, 2005 and 2009 for formulating strategies and measures in response to the impact of the United Nations Framework Convention on Climate Change and seeking a balance among economic development, energy supply, and environmental protection. During the past two decades, the Bureau of Energy under the Ministry of Economic Affairs (BEMOEA) has particularly promoted the research and development of renewable energies, which include (1) wind power generation; (2) photovoltalic energy (solar-PV); (3) solar thermal energy; (4) geothermal energy; (5) ocean energy; and (6) biomass energy. In addition, the Renewable Energy Development Bill was enacted for prompting the research and development of renewable energy in April 2010. Renewable energy is projected to reach $3 \%$ of the total energy supply by the year 2020. Furthermore, Taiwan has a subtropical climate (latitude $22^{\circ}$ to $25^{\circ}$ North), in which the average daily global solar insolation ranges from 1200 to $1700 \mathrm{kWh} / \mathrm{m}^{2} /$ year. The duration of sunshine per year is $2000-2500 \mathrm{~h}$ in southwestern regions and $1000-1500 \mathrm{~h}$ in northeastern regions. This climate is favorable for installing solar water heaters (SWHs) for producing hot water in both domestic and commercial sectors. This paper presents the status of SWH use in Taiwan, and addressed the effectiveness of the subsidy programs of the government as well as the barriers to market expansion.

Table 1. Energy supply in Taiwan.

\begin{tabular}{ccccccc}
\hline & $\mathbf{1 9 9 1}$ & \multicolumn{2}{c}{$\mathbf{2 0 0 1}$} & $\mathbf{2 0 1 1}$ & \\
\cline { 2 - 7 } & $\mathbf{1 0}^{\mathbf{3}} \mathbf{k L O E}$ & $\mathbf{\%}$ & $\mathbf{1 0}^{\mathbf{3}} \mathbf{k L O E}$ & $\mathbf{\%}$ & $\mathbf{1 0}^{\mathbf{3}} \mathbf{k L O E}$ & $\mathbf{\%}$ \\
\hline Total & 58,329 & & 106,383 & & 138,236 & \\
Indigenous & 1646 & 2.31 & 2462 & 4.1 & 2864 & 2.07 \\
Imported & 56,683 & 97.18 & 103,921 & 97.69 & 135,372 & 97.93 \\
\hline
\end{tabular}


Table 2. Indigenous energy supply.

\begin{tabular}{ccccccc}
\hline & \multicolumn{2}{c}{$\mathbf{1 9 9 1}$} & \multicolumn{2}{c}{$\mathbf{2 0 0 1}$} & \multicolumn{2}{c}{$\mathbf{2 0 1 1}$} \\
\cline { 2 - 7 } & $\mathbf{1 0}^{\mathbf{3}} \mathbf{k L O E}$ & $\mathbf{\%}$ & $\mathbf{1 0}^{\mathbf{3}} \mathbf{k L O E}$ & $\mathbf{\%}$ & $\mathbf{1 0}^{\mathbf{3}} \mathbf{k L O E}$ & $\mathbf{\%}$ \\
\hline hydropower & 368.4 & 22.38 & 487.5 & 19.80 & 382.4 & 13.35 \\
biomass and waste & - & - & 1096.0 & 44.52 & 1914.0 & 66.83 \\
PV and wind power & 1.7 & 0.10 & 0.1 & 0.00 & 149.2 & 5.21 \\
solar thermal & 24.9 & 1.51 & 81.1 & 3.29 & 113.2 & 3.95 \\
\hline
\end{tabular}

\section{SWHs in Taiwan}

Water heating constitutes one of the major types of household energy consumption [7]. It is important to optimize the operational energy consumption of hot water systems, including system type and size, system efficiency, hot water consumption patterns, and auxiliary fuel source. SWHs have been proven to be reliable and economical for producing hot water. Crawford and Treloar [8] also indicated that SWHs can pay back their embodied energy investment within four years, comparing with the equivalent conventional hot water systems. In the subsidy programs (1986-1991, 2000-present) offered by the BEMOEA, the cumulative area of solar collectors installed by the end of 2013 was 2.27 million $\mathrm{m}^{2}$. This is the most successful account of renewable energy application in Taiwan. The daily hot water consumption for each person generally corresponds to the hot water production, according to the area of solar collector installed $(A S C)$ of approximately $1 \mathrm{~m}^{2}$. According to the household structure, a system with an $A_{S C} \leq 10 \mathrm{~m}^{2}$ can be considered a residential system, whereas an SWH with an $A S C \geq 10 \mathrm{~m}^{2}$ is mainly ideal for rooming houses and industrial heating processes. A general survey of SWH users indicated that more than $98 \%$ of the SWHs were used for producing hot water in the domestic sector. This survey also indicated that the public attitude towards SWHs is critical for motivating first time users. Energy conservation (68\%) and safety $(26 \%)$ pose major concerns. Recommendation by local installers $(6 \%)$ or other SWH users $(9 \%)$ is another key factor. Therefore, the mass media should be used more aggressively for enhancing public awareness and promote the use of SWHs.

\subsection{National and Regional Subsidy Programs}

A national renewable energy policy is a vital prerequisite for translating customer choice into a larger market share for non-conventional energy technologies [9]. Apart from a relatively mature solar thermal technology, it is widely recognized that economic instruments play a key role in disseminating SWHs worldwide [10-14]. In particular, the subsidy associated with the AsC or thermal performance of an SWH has positive effects on economic viability. In Taiwan, the subsidy programs offered by the BEMOEA and regional governments constituted the major driving force for market expansion. As shown in Table 3, a subsidy calculated according to the ASC (NTD 2000 per $\mathrm{m}^{2}$ for glazed flat-plate and evacuated-tube solar collectors; NTD 1000 per $\mathrm{m}^{2}$ for unglazed flat-plate solar collectors) was granted with the purchase of an SWH, which met the 1986-1989 national standards regarding thermal performance. The amount of subsidy was halved from 1990 to 1991.

In 2000, the BEMOEA initiated another subsidy program (July 2000-present) for fostering the application of solar thermal energy. The National Cheng Kung University Research and Development 
Foundation is also authorized to organize an operation unit for performing the tasks, which include filing and auditing applications, allocating funds, and handling appeals. An SWH user is required to fill an application form, and a subsidy is granted according to the ASC and type of solar collectors installed (NTD 1500 per $\mathrm{m}^{2}$ for glazed flat-plate and evacuated tube solar collectors; NTD 1000 per $^{2}$ for unglazed flat-plate solar collectors). On remote islands, the amount of subsidy is doubled. For a large-scale system, a layout of the system and its design criteria are also required. A review committee then evaluates the proposal according to certain criteria including local weather conditions (sunshine hours, insolation and local average temperature) and field piping. The comments provided by the reviewers assist the installer in revising the system design. However, Chang et al. [15] indicated that this subsidy program is critical for promoting SWHs only at its initial stage, after which it loses momentum. For expanding the market, the BEMOEA introduced a revised subsidy program in 2009. The subsidy to the end users increased 50\% (NTD 2250 per $\mathrm{m}^{2}$ for glazed flat-plate and evacuated tube solar collectors; NTD 1500 per $\mathrm{m}^{2}$ for unglazed flat-plate solar collectors). Furthermore, Kinmen County (January 2008), Kaohsiung City (October 2008), and Penghu County (January 2012) announced regional subsidy programs for SWHs. An additional subsidy was offered to local households when an SWH is purchased, thus leading to a tremendous increase in sales. However, a high ratio of subsidy to capital cost (approximately 89\%) may distort net energy savings and negatively affect the long-term development of local markets [16]. Thus, a revised subsidy program was implemented in Kinmen County in April 2010.

Table 3. Subsidy programs in Taiwan.

\begin{tabular}{lcc}
\hline Funding Agency & Period & Collector-Area-Based Subsidies \\
BEMOEA & July 2000-December 2008 & $\begin{array}{c}\text { Direct subsidy, 1500 NTD } / \mathrm{m}^{2} \text { for glazed } \\
\text { flat-plate SC and evacuated tube SC; } \\
1000 \mathrm{NTD} / \mathrm{m}^{2} \text { for unglazed flat-plate SC }\end{array}$ \\
\hline BEMOEA & January 2009-present & $\begin{array}{c}\text { Direct subsidy, 2250 NTD } / \mathrm{m}^{2} \text { for glazed } \\
\text { flat-plate SC and evacuated tube SC; } \\
1500 \mathrm{NTD} / \mathrm{m}^{2} \text { for unglazed flat-plate SC }\end{array}$ \\
\hline $\begin{array}{l}\text { Government of } \\
\text { Kinmen county }\end{array}$ & March 2008-present & $\begin{array}{c}\text { Direct subsidy, the same amount as BEMOEA } \\
\text { Subsidizing up to } A_{S C}=6 \mathrm{~m}^{2} \text { after } 1 \text { April } 2010\end{array}$ \\
\hline $\begin{array}{l}\text { Government of } \\
\text { Kaohisung city }\end{array}$ & September 2008-December 2010 & $\begin{array}{c}\text { Direct subsidy, the same amount as } \\
\text { BEMOEA Subsidizing up to } 70 \% \text { of total cost }\end{array}$ \\
\hline $\begin{array}{l}\text { Government of } \\
\text { Penghu county }\end{array}$ & January 2012-present & Direct subsidy, 3000 NTD $/ \mathrm{m}^{2}$ \\
\hline
\end{tabular}

SC: solar collector; 1 USD $\approx 30$ NTD (New Taiwan Dollar).

\subsection{National Standards for Solar Collectors and SWHS}

Advanced technology is not required in manufacturing SWHs. Thus, the marketability of an SWH product cannot be solely based on word-of-mouth and previous experiences with the product rather than its efficiency and thermal properties [17]. Nevertheless, the quality of SWH installation and after-sale service may affect the reliable operation of an SWH. All products (flat-plate type or evacuated-tube type solar collectors, SWHs), installers/dealers, and manufacturers must possess a certification or license issued by the BEMOEA for them to be eligible for the subsidy programs. The 
experience of technicians also has a considerable effect on the selection of brands and respective manufacturers. Furthermore, one of the major objectives in the long-term subsidy programs launched by the BEMOEA is to enforce the standards of SWH application. Thermal performance tests of a solar collector (the Chinese National Standards, CNS 15165-1-K8031-1) or SWH (CNS 12558-B7277) are required when filing for a rebate. These standards specify outdoor test methods, conditions, and apparatus for determining the steady-state and quasi-steady-state thermal performance. Table 4 lists the standard of a solar collector in the subsidy programs (1986-1991, 2000-present). $F_{R}(\tau \alpha)$ and $F_{R} U_{L}$ are the slope and intercept of the collector efficiency curve, respectively. The standards require high useful energy collected from a collector (High $F_{R}(\tau \alpha)$ ) and low heat loss (low $F_{R} U_{L}$ ). In 2013, 140 solar collectors, in which the metallic glazed and unglazed flat-plate type solar collectors constituted $90.7 \%$, were certified. Furthermore, the utilization efficiency of an SWH, which should be greater than 50\%, is evaluated as the ratio of useful heat absorbed by an SWH to incoming solar energy on solar collectors. The list of certified products comprised 74 SWHs, including metallic flat-plate type (three systems), storage type (five systems), and evacuated-tube type (66 systems).

Table 4. Standard of flat-plate or evacuated-tube solar collectors (1986-1991; 2000-present).

\begin{tabular}{lcccccc}
\hline & \multicolumn{2}{c}{ Metal Type } & \multicolumn{2}{c}{ Non-Metal Type } & \multicolumn{2}{c}{ Unglazed Type } \\
\cline { 2 - 7 } & $\boldsymbol{F}_{\boldsymbol{R}}(\boldsymbol{\tau} \boldsymbol{\alpha})$ & $\boldsymbol{F}_{\boldsymbol{R}} \boldsymbol{U}_{\boldsymbol{L}}$ & $\boldsymbol{F}_{\boldsymbol{R}}(\boldsymbol{\tau} \boldsymbol{\alpha})$ & $\boldsymbol{F}_{\boldsymbol{R}} \boldsymbol{U}_{\boldsymbol{L}}$ & $\boldsymbol{F}_{\boldsymbol{R}}(\boldsymbol{\tau} \boldsymbol{\alpha})$ & $\boldsymbol{F}_{\boldsymbol{R}} \boldsymbol{U}_{\boldsymbol{L}}$ \\
\hline 1986 & $\geq 0.65$ & $\leq 12.0$ & & & & \\
1987 & $\geq 0.68$ & $\leq 10.0$ & $\geq 0.50$ & $\leq 10.0$ & $\geq 0.75$ & $\leq 25$ \\
1988 & $\geq 0.72$ & $\leq 8.0$ & $\geq 0.60$ & $\leq 8.0$ & $\geq 0.80$ & $\leq 22$ \\
$1989-1991$ & $\geq 0.75$ & $\leq 7.0$ & $\geq 0.65$ & $\leq 7.5$ & $\geq 0.85$ & $\leq 20$ \\
$2000-$ present & $\geq 0.75$ & $\leq 7.0$ & $\geq 0.65$ & $\leq 7.5$ & $\geq 0.85$ & $\leq 20$ \\
\hline
\end{tabular}

In 2000-2013, the top 10 SWH brands constituted 90\% of the local market. The market share of the glazed flat-plate type SWHs was more than 97\% in 2001 (Figure 1). The total area of solar collector installed per annum $\left(\Sigma A_{S C}\right)$ increased approximately $50 \%$ over the subsequent three years and peaked in 2006, followed by a decrease in 2007-2008. For the revised subsidy program in 2009, the $\Sigma A_{S C}$ increased gradually. The market share of the glazed flat-plate type, however, has been in a gradual decline since 2003. Nevertheless, the annual sales of evacuated-tube type SWHs increased considerably. Since 2007, the area of solar collector installed per annum is more than $10,000 \mathrm{~m}^{2}$, in which the market share approached $10 \%$, implying that the role of international competition has been increasing and may become stronger in the near future. Furthermore, the average $A_{S C}$ installed for flat-plate type and evacuated-tube type SWHs are approximately 5 and $3 \mathrm{~m}^{2}$, respectively.

\subsection{Historical Development of the SWH Market}

In the 1970s, the major industrial countries of the world faced substantial petroleum shortages. This energy crisis also triggered SWHs manufacturing in Taiwan. As shown in Figure 2, the $\Sigma A_{S C}$ before 1985 was less than $10,000 \mathrm{~m}^{2}$. The limited number of installed SWHs was attributed to their high capital cost compared with that of gas or electric water heaters. In the first subsidy program initiated by the BEMOEA, the SWH industry expanded rapidly (1986-1988) and the $\Sigma A_{S C}$ was approximately $60,000 \mathrm{~m}^{2}$. In the domestic sector, thermosyphon SWHs with glazed or unglazed flat-plate solar 
collectors were mainly used for producing hot water. From 1989 to 1991, the local SWH market varied slightly. By the end of the first subsidy program (1991), more than 58,000 SWHs were installed. In 1992-1995, the local SWH market continuously grew with a peak $\Sigma A S C$ of $90,000 \mathrm{~m}^{2}$ in 1995 . The accumulated $A S C$ was greater than $340,000 \mathrm{~m}^{2}$. The mature solar thermal technology and rapid economic growth were the key factors that led to the market expansion. The increase in current receipts and disposable income of each household rendered SWHs highly affordable; in addition, while quality control and cumulative experience of certified technicians were also attributed to the increased annual sales. Furthermore, the annual installation of SWHs slowed down in 1995-1999. The faltering economy and decline in new buildings were the major reasons [18].

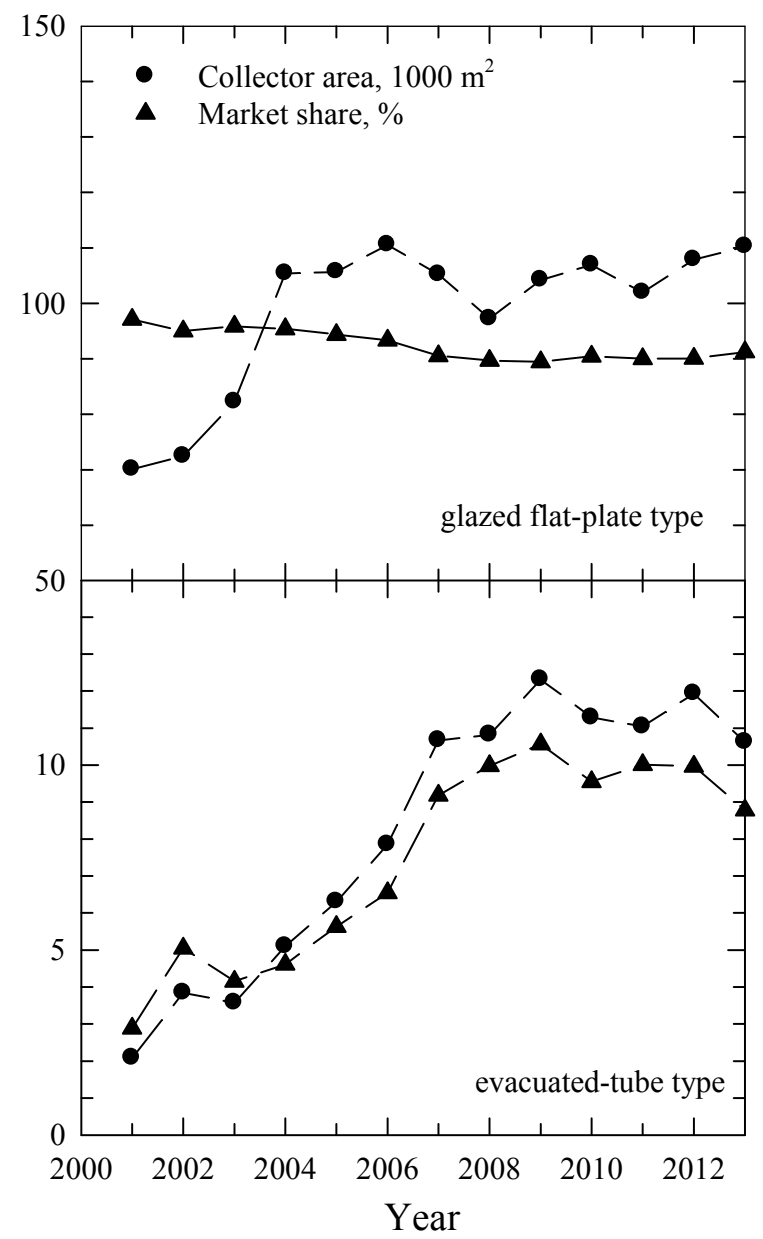

Figure 1. Annual sales of solar water heaters (SWHs) in terms of type of solar collector.

As mentioned previously, the second subsidy program was introduced in 2000, providing financial incentives for the end users and exerting a strong impact on the promotion of SWHs in Taiwan. The growth rate was approximately $29 \%$ in 2000 , and the $\Sigma A_{S C}$ exceeded $100,000 \mathrm{~m}^{2}$ since 2004; the $\Sigma A_{S C}$ doubled from 1999 to 2006 . However, the local market became rather stagnant in 2006-2008. A drop in 2009 corresponded to the global economic crisis, in which households were less motivated to install an SWH because of financial considerations (family disposal income and consumption expenditures). In summary, more than 0.27 million SWHs were installed from 2000 to 2013. Furthermore, a survey conducted by Chang et al. [18] indicated that nearly $14 \%$ of households replaced their old systems. In terms of a service life of 15 years, approximately 0.3 million systems (or 1.545 million $\mathrm{m}^{2}$ ) are in 
operation. This corresponds to an annual collector yield of $0.92 \mathrm{TWh}$, which is equivalent to savings of 98.7 thousand tons of oil and 319 thousand tons of $\mathrm{CO}_{2, \text { eq. }}$ According to the data of the Directorate General of Budget Accounting and Statistics [19], the total number of households in Taiwan was nearly 8.286 million in 2013. These statistics indicated that the popularization of residential SWHs was approximately $3.62 \%$ or $64 \mathrm{~m}^{2}$ per 1000 inhabitants, which represented only a small fraction of all households in Taiwan. Great potential still exists for active promotion of SWHs within the domestic sector in Taiwan.

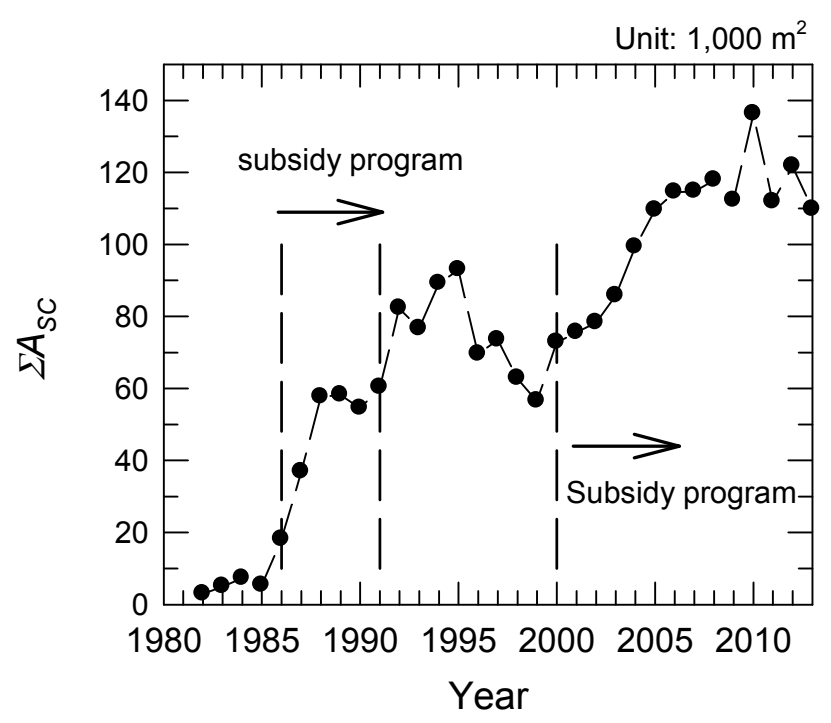

Figure 2. Area of solar collector installed per annum.

\section{Barriers to SWH Promotion}

$\mathrm{Wu}$ and Huang [20] reported that the barriers to the widespread diffusion of renewable energy technologies in Taiwan include technological advancements, the economy, institutions, laws, and public acceptance during the development process. For SWHs, Chang et al. $[15,18]$ reported that the major factors were economic/financial considerations, degree of urbanization, and legislative support. Labay and Kinnear [21] indicated that financial considerations are key elements in the decision process of consumer adoption. Because the capital cost of SWHs is considerably higher than that of gas or electric water heaters, average family disposable income is a vital factor in consumer adoption decisions. Another vital factor is the monetary benefit accrued to end users, and this hinges on the cost of fuel saved when using SWHs. In addition, apartments and group housing constitute the major types of residence in Taiwan's metropolitan areas. The degree of urbanization (types of building architecture) may limit the locations available for installing SWHs. Therefore, building-integrated solar thermal systems must be developed for disseminating SWHs in the metropolitan areas. Household composition would be another influencing factor.

\subsection{Economic Aspects}

The economic feasibility of SWHs is mainly determined by their initial cost, long-term efficiency, and payback period. A household would be willing to invest in purchasing an SWH provided that the 
capital and maintenance costs are less than a specific fraction of the household's disposal income. As shown in Figure 3, low average family disposal income in the early 1980s resulted in limited SWH installation. However, the rapid economic growth and introduction of the first subsidy program around the 1990s rendered SWHs more affordable. In addition, gas or electric water heaters have been widely used in Taiwan. Considering energy savings shows that the monetary benefits accrued to an end user depend on the amount and cost of electricity or fuel saved through the life service of an SWH. As a state-owned public utility, the Taiwan Power Company has restricted the fluctuations of electricity rates to fulfill the governmental energy policy. However, lower electricity rates result in a longer payback period for SWHs. By contrast, a drastic increase in the price of natural gas or liquefied petroleum gas for gas water heaters during the past few years has led to increased annual fuel savings for an SWH installed.

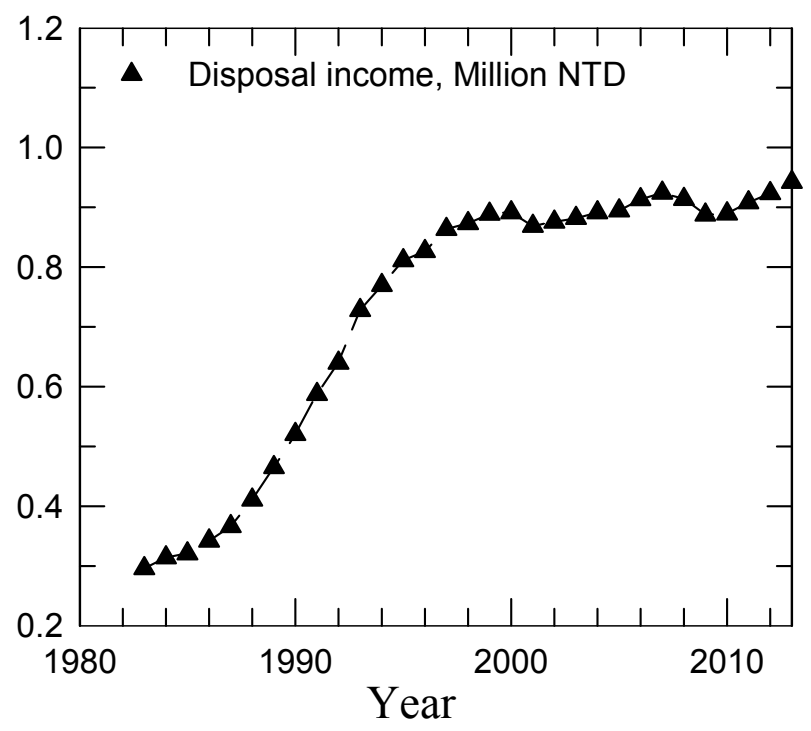

Figure 3. Average family disposal income.

Apart from energy prices, incentives, and total installed costs, the economic payback period of an SWH also depends on solar insolation, hot water consumption, and the expected service life of installation [12]. Pan et al. [22] reported that the economic payback period in Taiwan ranged from 6 to 15 years. However, the actual hot water consumption of each household in different districts is not clearly understood; therefore, the payback period may be underestimated. Furthermore, the effect of economic viability on the SWH market expansion in Taiwan is similar to that of international experiences [23]. The efficiency of financial incentives can be valued according to their roles in reducing the effective total installation cost for the end user. Inappropriately designed subsidy programs could end up being counterproductive. From 2000 to 2009 , the ratio of the subsidy to total installation cost was approximately $20 \%$ in Taiwan. For the subsidy programs implemented by the regional governments, the ratios in Kaohsiung City and Kinmen County in 2009 were 50\% and 89\%, respectively [16]. The average $A S C$ increased from 3.43 to $5.95 \mathrm{~m}^{2}$ for residential SWHs in Kinmen County. Because the ratio of household size to $A S C$ is approximately equal to 1 in common practice, some SWHs deployed in Kinmen County were considered to be overdesigned. This resulted in discrepancies between demand and hot water production, and the net energy saving was consequently misrepresented. 


\subsection{Residential Systems (Types of Building Architecture and Household Structures)}

Barring local climatic conditions, Chang et al. [15] reported that the degree of urbanization and household structures were also key factors influencing the dissemination of SWHs in Taiwan. Because most SWHs were installed on the flat roofs of buildings, available installation sites were essentially associated with the types of building architectures, in which approximately $75 \%$ of SWHs were installed on the flat roofs of three- and four-story houses. However, apartments and group housing are the major types of housing in urban areas (e.g., Taipei City and New Taipei City). Related architectural laws should be amended in favor of SWH installation. The architectural integration is also important in the spreading of solar thermal technologies [24] and developing building-integrated solar thermal systems. Chang et al. [15] also indicated that the promotion of SWHs was strongly related to the number of new buildings. As illustrated in Figure 4, in 2009-2013, 55\% of SWHs were installed in buildings constructed within three years. Furthermore, Figure 5 depicts the status of occupancy permits for one- to five-story houses. The construction sector boomed in 2006 (62,923 units), declined between 2007 (57,525 units) and 2009 (25,154 units) and increased from 2010 (33,711 units) to 2012 (39,709 units). This partially corresponded to the stagnant SWH market (Figure 3). However, for the revised national subsidy program in 2009, the financial incentives resulted in an increase of $31.4 \%$ for old buildings that installed SWHs. A few SWHs were also installed in eastern Taiwan, and this was associated with the high rate of vacant houses.

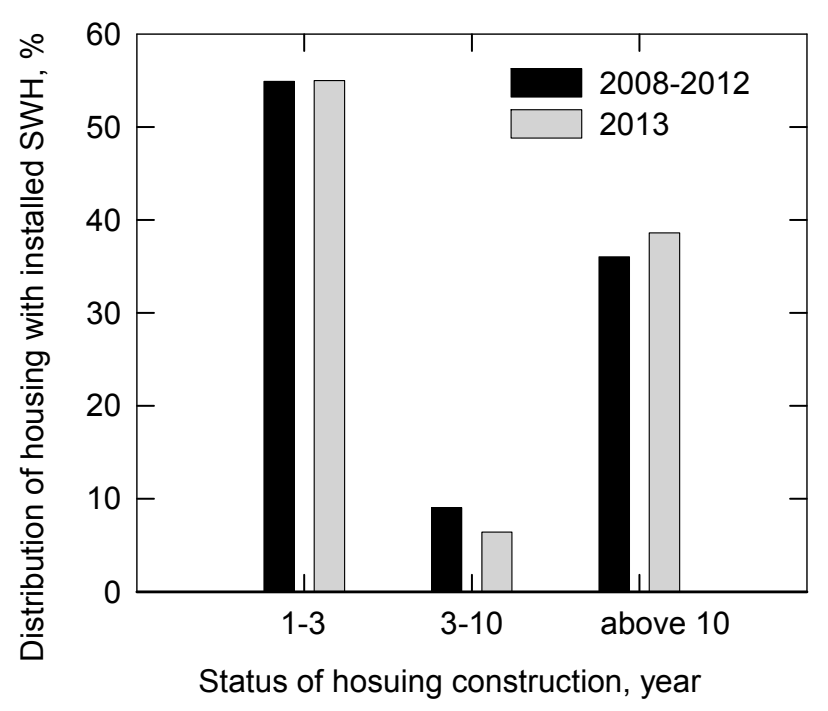

Figure 4. Status of house construction with SWH installed.

As previously mentioned, a rule of thumb for designing a residential SWH system is that the ASC per person is approximately equal to 1 . The $A S C$ of most systems (more than $80 \%$ ) ranged from 3 to $10 \mathrm{~m}^{2}$. As illustrated in Figure 6, 0.96\% of households using SWHs are one-person households. A family size of four-six persons is more favorable for installing an SWH (nearly 75\% users). However, because of the outflow of employed population, schooling population, or marital status, one-person households (30.5\%) have gained the highest level among the total number of households [19]. In addition, the unit price of an SWH decreased with a large $A_{S C}$ [18]. Thus, applying larger scale systems may benefit from the economies of scale. A high unit price with a subsequent long economic payback period is another 
critical concern that must be addressed in marketing campaigns. Further, Crawford and Treloar [8] indicated that the embodied energy for SWHs is insignificant in terms of its net energy consumption. To minimize operational energy consumption, the solar fraction (ratio of the solar heat yield to the total energy required for hot water production) can be used as an indicator of energy payback period. In Taiwan, the values of solar fraction range from 0.4 to 0.9 . Location of SWHs installed and hot water consumption patterns are among the dominant factors. Nevertheless, more studies should be done in improving the energy return or energy payback period of SWHs.

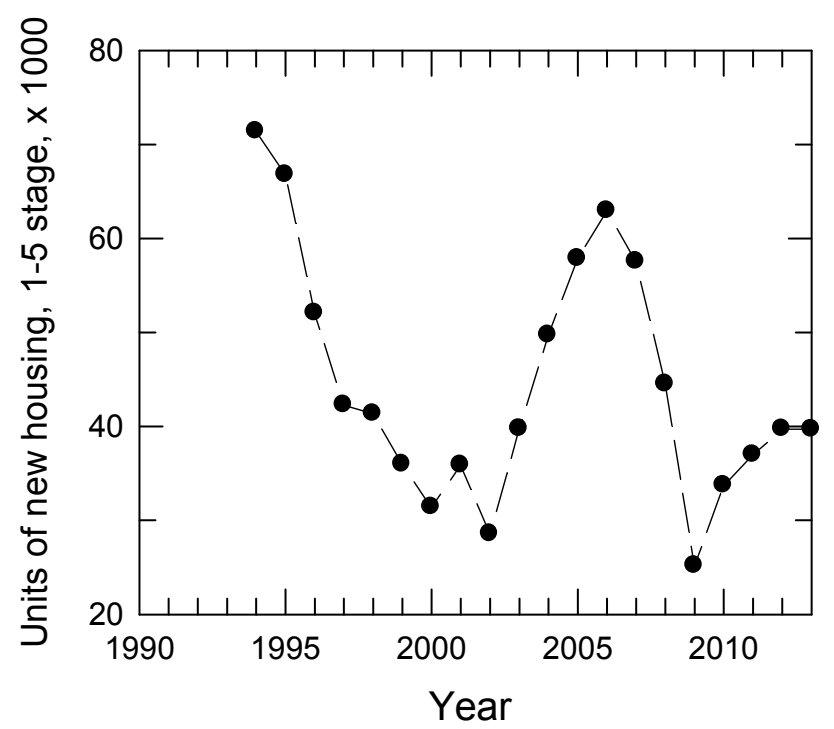

Figure 5. Usage licenses for houses with 1-5 stages.

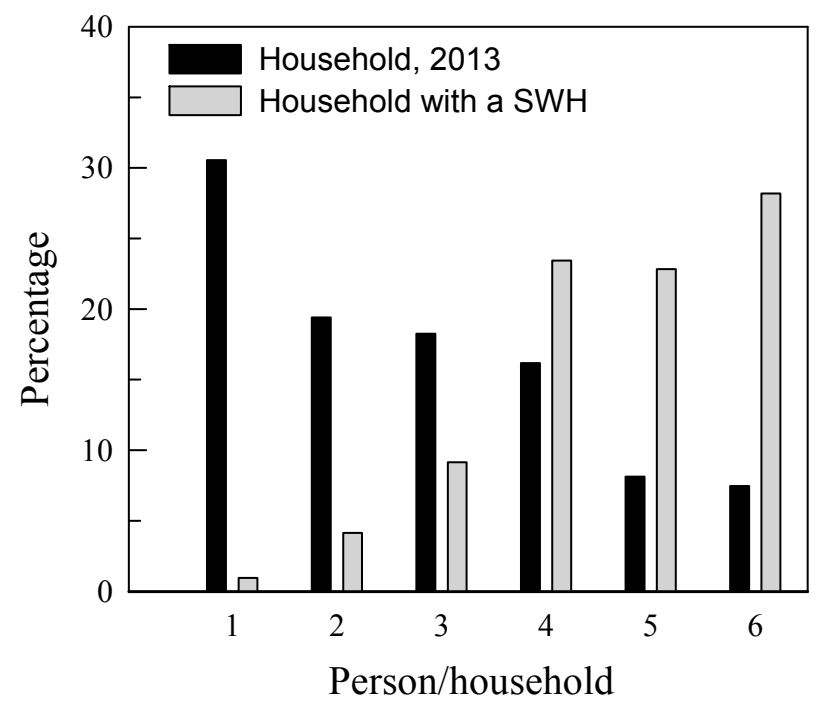

Figure 6. Household structure.

\subsection{Large-Scale Systems (System Design and Maintenance)}

In 2000-2013, more than 98\% of SWHs were used for producing hot water in the domestic sector, and the $A_{S C} \leq 10 \mathrm{~m}^{2}$. Only 154 systems with $A_{S C}>100 \mathrm{~m}^{2}$ were implemented for dormitories, 
swimming pools, manufacturing plants and restaurants. In addition, only a few installers designed more than 10 systems during this period, indicating the lack of experience in large-scale system design among most installers. Furthermore, a large-scale SWH is generally integrated with a kerosene heater as an auxiliary element. Regarding utilization efficiency, field piping and regulating hot water supply are critical factors in system design. Lin et al. [25] conducted a field survey of a dormitory system. The daily records indicated that hot water consumption was mostly concentrated in certain periods. According to the daily heating energy required for producing hot water, the solar fraction was less than $50 \%$. The measured data also showed that the overnight water temperature at the upper level in the storage tanks exceeded $35^{\circ} \mathrm{C}$, indicating an improper operation of the auxiliary heater (energy waste) and low utilization efficiency.

Maintenance is another critical concern for long-term operation of a large-scale SWH. This is generally associated with after-sale service and technical support. However, most large-scale systems in Taiwan have not been adequately maintained because of maintenance negligence or unqualified maintenance staff. Gate valve leakage and deteriorated sealing have been reported occasionally, and thermal insulation degradation is common. Low thermal efficiency of solar collectors can also be expected when dust accumulates on the glass surface. Thus, the government should play an integral role by providing intensive courses to managers and technicians. Strong emphasis must be placed on training all market players to enhance their technical knowledge and customer service levels. In addition, Islam et al. [26] reported that a large-scale SWH is more financially attractive compared with that in the domestic sector. More efforts must be placed in prompting SWHs for industrial heating processes. Therefore, the BEMOEA must introduce alternative financial incentives (e.g., performance-based subsidy program).

\subsection{Wind Loads}

Thermal performance and energy savings are definitely the primary concerns of SWH users. However, typhoons frequently occur over the western North Pacific and South China Sea each year and some of them affect Taiwan in the summer and autumn. Because most SWHs are installed on the flat roofs of buildings, typhoon attacks must be considered when designing the aerodynamic characteristics of solar collectors and supporting structures. The glass covers of solar collectors, in particular, are often broken by strong wind uplift because of the associated high deflection (Figure 7). The wind uplift produced by typhoons must be considered when installing SWHs in Taiwan. Previous studies conducted by Radu et al. [27,28] investigated the characteristics of steady-state wind loads of solar collectors in clusters on the flat roofs of five-story buildings in a boundary-layer wind tunnel. They discovered that the sheltering effects of the first row of collectors and of the building itself considerably reduced the wind loads exerted on the solar collectors. The flat-plate solar collectors with glass covers are widely used in Taiwan. Chung et al. [29,30] reported that the localized loads of a glazed flat-plate solar collector were higher near the front edge. The wind uplift of a solar collector considerably increased with the tilt angle $(\beta)$ of the collector for both residential (a tilt solar collector with a horizontal cylinder as water storage tank) and large-scale (tilt solar collectors only) SWHs (Figure 8). A reduction in wind uplift should be addressed to prevent the devastating damage caused by typhoons. 


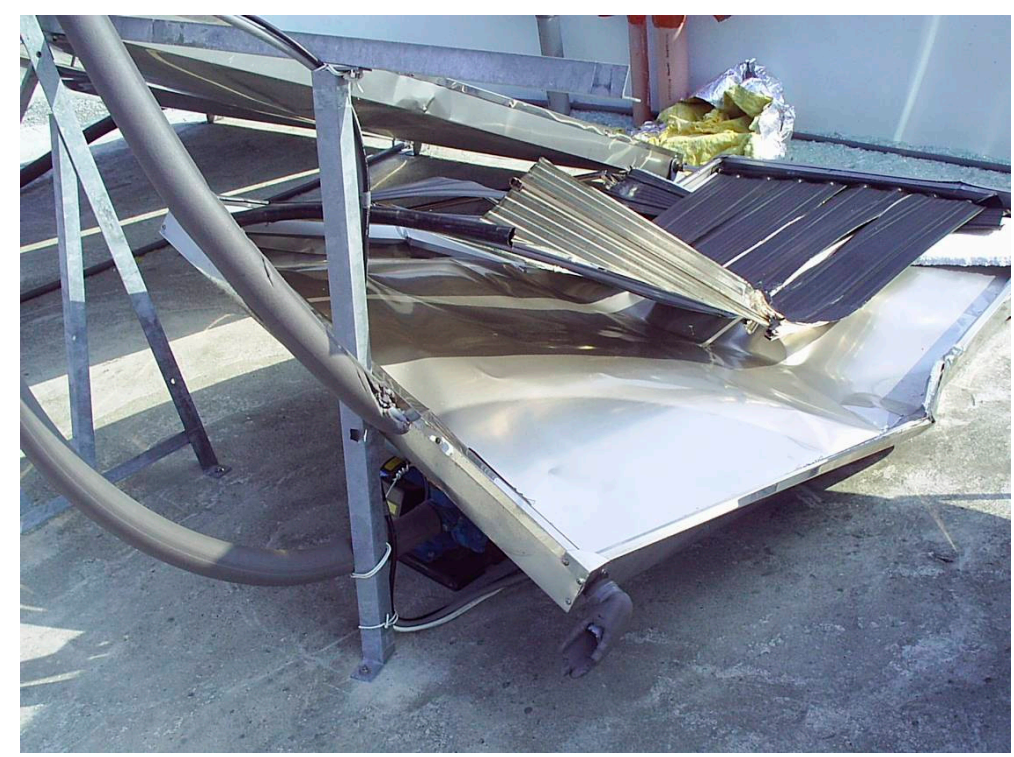

Figure 7. Solar collector damaged by typhoon.

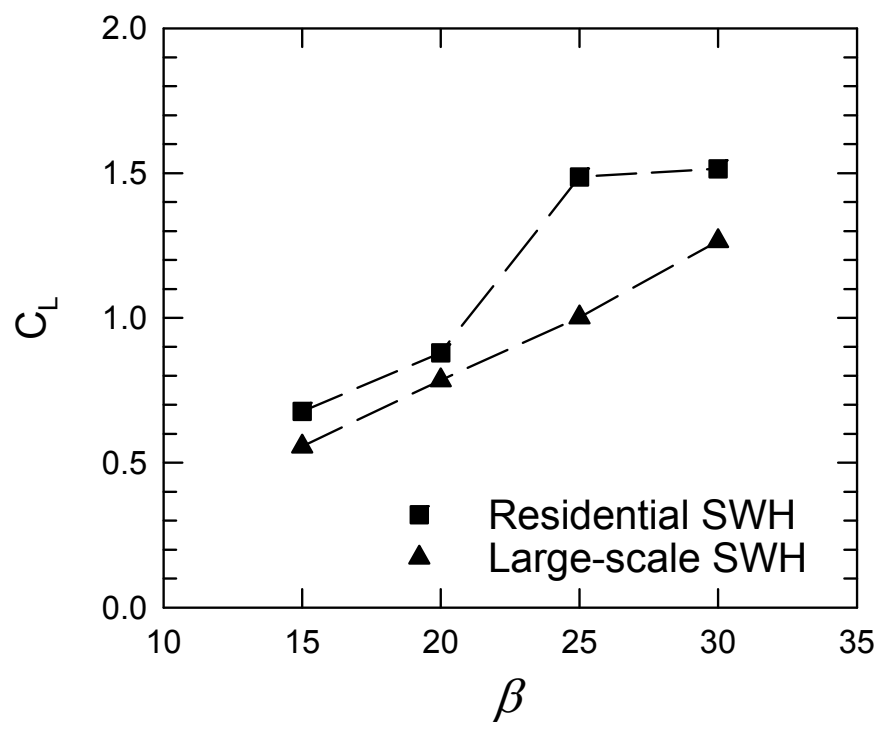

Figure 8. Uplift coefficient of solar collector.

\section{Conclusions}

The well-orchestrated and concerted efforts introduced by the government of Taiwan, particularly with the Renewable Energy Development Bill promulgated in 2010, have played a crucial role in the increased dissemination of SWHs. However, a more aggressive legislation that requires mandatory installation in new constructions must be implemented. The long-term national subsidy programs constitute the main driving force for local market expansion. For maintaining a free and open market, subsidies must be implemented only throughout the business phase. The negative impact of cross-subsidy programs implemented by the regional governments on the long-term development of the local market should be carefully addressed. The mass media should be used more aggressively for enhancing public awareness and promoting the use of SWHs. Organizations must also consider the interests of society by being accountable for their business practices and being responsible for the impact of their activities 
on the environment (reduction of carbon emissions). Finally, alternative subsidy programs for building-integrated solar thermal collectors and industrial heating processes are required for sustainable development of solar heating systems in Taiwan.

\section{Acknowledgments}

This work was supported by the Bureau of Energy, Ministry of Economic Affairs (102-D0303), Taiwan, Republic of China.

\section{Author Contributions}

Keh-Chin Chang was the principal investigator and edited the manuscript. Wei-Min Lin carried out the analysis of SWH market in Taiwan. Kung-Ming Chung drafted the manuscript. All authors read and approved the final manuscript.

\section{Acronyms}

$(\tau \alpha) \quad$ Value of transmissivity and absorptivity for solar energy

ASC Area of solar collector, $\mathrm{m}^{2}$

BEMOEA Bureau of Energy, the Ministry of Economic Affairs

CNS Chinese National Standards

$F_{R}(\tau \alpha) \quad$ Slope of the collector efficiency curve

$F_{R} U_{L} \quad$ Intercept of the collector efficiency curve

kLOE Kiloliter of oil equivalent

NTD New Taiwan Dollar

PV Photovoltaic

SWHs Solar water heaters

SC Solar collector

$\beta \quad$ Tilt angle of solar collector

SAsc Total area of solar collector installed per annum

\section{Conflicts of Interest}

The authors declare no conflict of interest.

\section{References}

1. Katinas, V.; Markevicius, A. Promotional policy and perspectives of usage renewable energy in Lithuania. Energy Policy 2006, 34, 771-780.

2. Chen, F.L.; Lu, S.M.; Wang, C.C.; Chang, Y.L. Promotion strategies for renewable energy in Taiwan. Renew. Sustain. Energy Rev. 2008, 12, 1681-1691.

3. Uduma, K.; Arciszewski, T. Sustainable energy development: The key to a stable Nigeria. Sustainability 2010, 2, 1558-1570. 
4. Stablo, J.; Ruppert-Winke, C. The integration of energy conservation into the political goal of renewable energy self-sufficiency-A German case study based on a longitudinal reconstruction. Sustainability 2012, 4, 888-916.

5. Mauthner, F.; Weiss, W. Solar Heat Worldwide; AEE-Institute for Sustainable Technologies: Gleisdorf, Austria, 2014.

6. Bureau of Energy, Ministry of Economic Affairs (BEMOEA). 2012 Energy Statistical Data Book; Bureau of Energy, Ministry of Economic Affairs: Taipei, Taiwan, 2013. Available online: http://web3.moeaboe.gov.tw/ (accessed on 17 December 2014).

7. Hu, T.C.; Yoshin, H. Analysis on energy consumption and indoor environment in Kunming, China. Sustainability 2012, 4, 2574-2585.

8. Crawford, R.H.; Treloar, G.J. Net analysis of solar and conventional domestic hot water systems in Melbourne, Australia. Sol. Energy 2004, 76, 159-163.

9. Srinivasan, S. Subsidy policy and enlargement of choice. Renew. Sustain. Energy Rev. 2009, 13, 2728-2733.

10. Argiriou, A.A.; Mirasgedis, S. The solar thermal market in Greece-review and perspectives. Renew. Sustain. Energy Rev. 2003, 7, 397-418.

11. Chandrasekar, B.; Kandpal, T.C. Tech-economic evaluation of domestic solar water heating systems in India. Renew. Energy 2004, 29, 319-332.

12. Kaldellis, J.K.; Kavadias, K.A.; Spyropoulos, G. Investigating the real situation of Greek solar water heating market. Renew. Sustain. Energy Rev. 2005, 9, 499-520.

13. Cassard, H.; Denholm, P.; Ong, S. Technical and economic performance of residential solar water heating in the United States. Renew. Sustain. Energy Rev. 2011, 8, 3789-3800.

14. Shukla, R.; Sumathy, K.; Erickson, P.; Gong, J. Recent advances in the solar water heating systems: A review. Renew. Sustain. Energy Rev. 2013, 19, 173-190.

15. Chang, K.C.; Lee, T.S.; Lin, W.M.; Chung, K.M. Outlook for solar water heaters in Taiwan. Energy Policy 2008, 36, 66-72.

16. Chang, K.C.; Lin, W.M.; Lee, T.S.; Chung, K.M. Subsidy programs on diffusion of solar water heaters: Taiwan's experience. Energy Policy 2011, 39, 563-567.

17. Kalogirou, S. Solar thermal collectors and applications. Progress Energy Combust. Sci. 2004, 20, 231-295.

18. Chang, K.C.; Lin, W.M.; Lee, T.S.; Chung, K.M. Local market of solar water heaters in Taiwan: Review and perspectives. Renew. Sustain. Energy Rev. 2009, 13, 2605-2612.

19. Directorate General of Budget Accounting and Statistics (DGBAS). Key economic and social indicators. Available online: http://www.dgbas.gov.tw (accessed on 17 December 2014).

20. Wu, J.H.; Huang, Y.H. Renewable energy perspectives and supporting mechanisms in Taiwan. Renew. Energy 2006, 31, 1718-1732.

21. Labay, D.; Kinnear, T. Exploring the consumer decision process in the adoption of solar energy systems. J. Consum. Res. 1981, 8, 271-278.

22. Pan, T.C.; Kao, J.J.; Wong, C.P. Effective solar radiation based on benefit and cost analysis for solar water heater development in Taiwan. Renew. Sustain. Energy Rev. 2012, 16, 1874-1882.

23. Roulleau, T.; Lloyd, C.R. International policy issues regarding solar water heating, with a focus on New Zealand. Energy Policy 2008, 36, 1843-1857. 
24. Munari Probst, M.C.; Roecker, C. Towards an improved architectural quality of building integrated solar thermal systems (BIST). Sol. Energy 2007, 81, 1104-1116.

25. Lin, W.M.; Chang, K.C.; Liu, Y.M.; Chung, K.M. Field surveys of non-residential solar water heater in Taiwan. Energies 2012, 5, 258-269.

26. Islam, M.R.; Sumathy, K.; Khan, S.U. Solar water heating systems and their market trends. Renew. Sustain. Energy Rev. 2013, 17, 1-25.

27. Radu, A.; Axinte, E.; Theohari, C. Steady wind pressures on solar collectors on flat-roofed buildings. J. Wind Eng. Ind. Aerod. 1986, 23, 249-258.

28. Radu, A.; Axinte, E. Wind forces on structures supporting solar collectors. J. Wind Eng. Ind. Aerod. 1989, 32, 93-100.

29. Chung, K.M.; Chang, K.C.; Liu, Y.M. Reduction of wind uplift of a solar collector model. J. Wind Eng. Ind. Aerod. 2008, 96, 1294-1306.

30. Chung, K.M.; Chang, K.C.; Chou, C.C. Wind load on residential and large-scale solar collector models. J. Wind Eng. Ind. Aerod. 2011, 99, 59-64.

(C) 2015 by the authors; licensee MDPI, Basel, Switzerland. This article is an open access article distributed under the terms and conditions of the Creative Commons Attribution license (http://creativecommons.org/licenses/by/4.0/). 